In an effort to resolve this confusion for the credentialers and the patients, all member boards of the ABMS agreed to establish parameters under which noncertified physicians could actually be recognized as being board eligible and to further define the time limit for such eligibility status.

The ABFM Board of Directors decided at its meeting in October 2011 that it would define board eligibility as the first 7 years after loss of certification or the completion of an ACGME accredited residency training program. Therefore, beginning January 1, 2012, a physician will have 7 years in which to successfully complete his or her initial certification examination after completing training or, if previously certified, will have 7 years after the loss of certification to successfully complete the examination.

During this 7-year period, these board-eligible physicians will have to continue to meet the ongoing requirements to sit for the examination and must maintain a full, valid, and unrestricted license. After this 7-year period, the physician will lose the ability to refer to himself or herself as board eligible and will need to re-enter training and complete at least 1 year of additional training in an ACGME-accredited family medicine residency before he or she will be allowed to reapply to sit for the examination. This rule will be effective January 1, 2012. As further details of the program are developed they will be published.

Robert Cattoi

American Board of Family Medicine

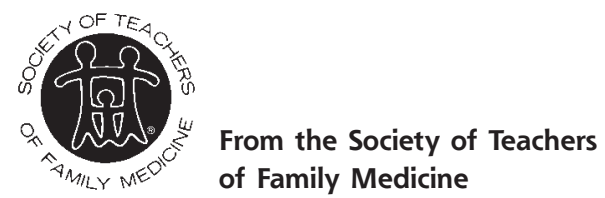

Ann Fam Med 2012;10:177-178. doi:10.1370/afm.1388.

\section{AN IMPERATIVE FOR 2012 AND BEYOND: STEP UP AND ADVOCATE FOR ACADEMIC FAMILY MEDICINE}

STFM has the privilege of leading the advocacy effort for the 4 academic family medicine organizations that make up the Council of Academic Family Medicine (CAFM). We lead and staff the Academic Family Medicine Advocacy Committee (AFMAC) which has representatives from the CAFM organizations, as well as the AAFP. One of the 3 main goals of the CAFM organizations is to provide a unified voice for academic family medicine, and a key part of the STFM strategic plan is advocacy.
With advocacy for academic family medicine as its mandate, AFMAC has been critically involved in the development of policy on issues such as Medicare graduate medical education reform and Title VII primary care training funding. Our efforts to translate our policy interests into action require the involvement of the membership of all the CAFM organizations. We have designed a portfolio of tools and systems to aid our members in this activity. Within this portfolio is information on our online advocacy course and our new grassroots advocacy network

About a year ago we unveiled the online advocacy course. This course is free to family medicine physicians, educators, residents, and students. It delivers a quick yet complete course of several modules with the skills needed to begin work in the advocacy arena. It takes less than an hour to complete and one can take it in several sittings. You can go to http://stfm.org/ advocacy to register for the course. In combination with the Family Medicine Congressional Conference (FMCC) in the spring of each year, CAFM members can earn a certificate of achievement as a family medicine advocate

We are excited to share a significant new effort this year, the creation and development of a grass roots advocacy network. Each department chair and residency director is being asked to name a member of their faculty to be the CAFM Advocacy Network (CAN) Representative for their program or department. The basic strategy is to have a motivated person in each department or program acting as a key advocate to respond to alerts and inform their colleagues, as a way to help amplify our advocacy efforts. Each CAFM Advocate will receive national recognition as your program or department's advocacy representative, recognition within their program as an expert on federal academic family medicine issues, ongoing support from CAFM's Government Relations office in Washington, DC, including a brief information sheet about your representative/senators, access to the aforementioned free online advocacy course to learn the skills needed to be an effective advocate, and the opportunity to develop enhanced leadership and negotiation skills. A key aspect of this effort is to teach our members to report their advocacy activities and their response to our alerts with a form they can find on the STFM website. There is a new email address cafmadvocacy@stfm.org for all CAN representatives who have questions about legislative issues or advocacy in general. The CAN network is off to a terrific start with over 50 persons signed up in the first month. Anyone who would like to join us as a CAFM Advocate can go to http://www.stfm.org/advocacy/network.cfm to find out more about this program and can sign up by 
emailing your name and all your contact information to cafmadvocacy@stfm.org.

Turning from our theoretical plans to expand our advocacy efforts to specific advocacy goals, we have had some success moving forward with our Medicare primary care graduate medical education reform pilot. The concept of this reform pilot was developed in the fall of 2008 and has been a key advocacy effort of CAFM and the AAFP since then. Briefly, our proposal would direct a share of existing GME funding to specific pilot projects to test 4 different models of primary care training. Payments would be made by Medicare in a similar manner as the current GME payment process, but to the medical education entities (based on the number of residents training), rather than directly to hospitals. The bill authorizes the Secretary of HHS to test 2 sites for each of these 4 models: a community entity working with 2 or more hospitals; 2 hospitals working together to develop a primary care program; a hospital subsidiary or independent corporation working with the community to further primary care; and a medical school/university collaborating with a hospital. In addition, these entities would be allowed to grow their complement of residents by $50 \%$ for the term of the pilot (until completion of residency) without an impact on a hospital's resident cap.

In December, a bill to legislate the pilot was introduced in the House of Representatives. The bill, HR 3667, the Primary Care Workforce Access Improvement Act of 2011, was introduced by Representatives Cathy McMorris Rodgers (R-WA) and Mike Thompson (D-CA). We are now in the process of encouraging other representatives to sign on as cosponsors. This will be a first test of our CAN members as well-asking that they respond to our GME alert. For more information about the bill, including talking points, FAQ's, etc, as well as how to respond to the alert, please go to http://www.stfm.org/advocacy/index.cfm.

As the current session of Congress moves forward, there is another key arena that we will need committed advocacy support. Discretionary health spending is under the eye of appropriators for cuts. As part of the Budget Control Act of 2011, approximately 1.2 trillion dollars in cuts must be made or an automatic reduction of funding, called a sequester, will occur. At risk are all health programs we care about, including Title VII, primary care training, funding for the Agency for Healthcare Research and Quality (AHRQ), as well as cuts to entitlement funding, such as Medicare GME payments.

We look to all of the family of family medicinemembers of the CAFM organizations and AAFP - to help us in our advocacy efforts in the coming year and beyond. If advocacy has not yet been an arena you have entered, please consider making it a priority for your development as a faculty member. We need everyone to be involved as we struggle to build and sustain the infrastructure of family medicine education and scholarship.

Should you have any questions please feel free to contact us at cafmadvocacy@stfm.org.

Mary N. Hall, MD, Academic Family Medicine Advocacy Committee $_{i}$ Hope Wittenberg, MA, Government Relations

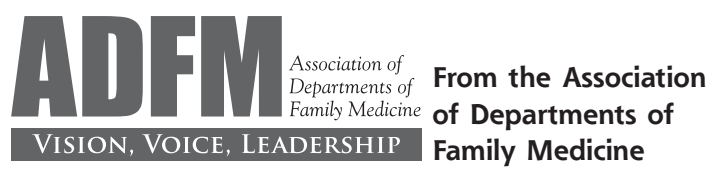

Ann Fam Med 2012;10:178-179. doi:10.1370/afm.1389.

\section{PRODUCING FAMILY PHYSICIANS: OUR MEDICAL SCHOOLS MUST DO A BETTER JOB}

The low number of US medical students choosing careers in family medicine is no longer a concern limited to our discipline. National groups including MedPac, the Commonwealth Fund, Kaiser Family Foundation, the Patient-Centered Primary Care Collaborative (PCPCC), and others have also expressed serious concern. Despite a recent slight uptick in student interest, we are far below our peak and the longer-term trend is down. For the 10-year period 2001 to 2010 an average of 1,430 students per year entered FM training (average per school $11.35,9.1 \%$ ), but for the most recent 3 years of that period, 2008 to 2010, it was down to an average of 1,317 per year (average per school 10.5, 8.1\%.) ${ }^{1}$; osteopathic schools are also experiencing a decline. ${ }^{2}$ And it was never enough. About $30 \%$ of practicing physicians in the United States are in primary care, while in most developed countries with a well-functioning health system it is closer to $50 \%$. We will not get to $50 \%$ by producing less than $20 \%$ per year.

While some have suggested that the income gap between primary care and subspecialty physicians may be the largest single cause of this phenomenon, ${ }^{3}$ it is still one among many, and it is one over which medical school educators have little control. It also does not explain the variation between schools in producing family doctors. The areas in which faculty can most effectively work for change are who is admitted to medical school and the experience that students have while in school.

The AAFP annually recognizes the medical schools that graduate the highest percentage of students 